\title{
EFEKTIVITAS KEPEMIMPINAN; Sebuah Kajian Teoritis
}

\author{
Mardalena \\ Prodi Pendidikan Bahasa Inggris - Komplek STKIP Y PM Bangko. Sudirman Km 2, \\ Kelurahan Pematang Kandis, Kecamatan Bangko, Kabupaten Merangin, Jambi \\ email: mardalena17@gmail.com
}

\begin{abstract}
Leadership is as the main character that will determine the progress and competitive advantage to an organization. Leaders are expected to bring the institution achieve performance exceeding expectations in a sustainable manner. In difficult conditions is very important for a leader to control the organization towards a clear and consistent effectively and simultaneously anticipate and respond to the demands of the future. Leadership role in making a choice of a wide range of alternatives that are considered most appropriate. Therefore, we need effective leader, a leader who is able to use the powers available to him as a good and constructive, leadership capable of formulating clear goals and achievable based on the ability of the existing resources, leaders are able to communicate to its members what he was thinking, leadership wise, where in the face and solve problems always puts the ratio by keeping in mind the taste. He stressed that effective leadership is a strong leader who is fighting for the ideals to be achieved.
\end{abstract}

Key word: Effective Leader, goal achievement

\section{PENDAHULUAN}

Anwar dalam tulisan Ady Wicaksono kepemimpinan memegang peranan penting bagi pencapaian efektivitas organisasi. Pimpinan memiliki kapasitas dalam mempengaruhi orang lain untuk berperilaku sesuai harapan organisasi. Di samping itu, seorang pimpinan yang memiliki kemampuan merumuskan dan mengartikulasikan visi organisasi akan dapat menentukan efektivitas organisasi di masa depan. Kemudian, Riggio dikutip oleh Yvete Ramchunder efektivitas organisasi juga bergantung kepada efektivitas pimpinan.

a. Defenisi Kepemimpinan

Kepemimpinan adalah kemampuan menggunakan pengaruh dan memotivasi individu untuk mencapai tujuan organisasi. Pimpinan organisasi dapat mempengaruhi perilaku dengan cara menciptakan sistem dan proses organisasi yang sesuai dengan kebutuhan, baik kebutuhan individu, kebutuhan kelompok maupun kebutuhan organisasi. Menurut Hogan et al, dikutip oleh Yvete kepemimpinan itu dalam rangka meyakinkan orang lain sehingga ia fokus dan berupaya mencapai tujuan organisasi. Kehebatan pimpinan juga kemudian dihubungkan dengan kehebatan anggotanya.

Kepemimpinan kemudian juga merupakan interaksi setiap anggota dalam sebuah kelompok. Pimpinan juga merupakan seorang agen perubahan, di mana tindakan seseorang akan mempengaruhi orang lain. Kemudian bahwa kepemimpinan kemudian juga melibatkan pencapaian tujuan. Seorang pimpinan yang efektif tentunya adalah manakala mampu mensinergikan tujuan individu, kelompok dan organisasi. Model efektivitas pimpinan menurut Ivancevic et al.,

Model efektiftas yang diilustrasikan di atas, memperlihatkan efektivitas kepemimpinan secara holistik. Diperlukan beberapa faktor 
dan aspek pendukung guna menjadi pimpinan yang efektif. Hal ini bermula dari diri pimpinan itu sendiri. Hal ini terkait dengan kemampuan, personaliti serta motivasi. Kemudian sikap pimpinan juga menjadi aspek penting, baik berorientasi kepada tugas, individu, kepemimpinan transformatif. Tidak berhenti di situ, menjadi pimpinan yang efektif memerlukan dukungan dari anggota, baik berupa rasa percaya, kewenangan atasan dan pembagian tugas yang terstruktur dan jelas. b. Landasan Kepemimpinan

Menurut Robbins dikutip oleh Wicaksono kepercayaan adalah landasan dari kepemimpinan. Kepercayaan merupakan pengharapan positif bahwa orang lain tidak akan melakukan tindakan yang mengundang resiko dan kerentanan di dalam setiap hubungan. Dimensi kunci yang melandasi konsep kepercayaan itu antara lain adalah: integritas, kompetensi, konsistensi, loyalitas, dan keterbukaan.

Kepemimpinan yang baik, tidak hanya sebatas perhitungan dan perencanaan, melakukan checklist, bahkan analisis rasional, namun pimpinan yang baik adalah juga kemampuan dalam menyentuh hati, perasaan dan emosional para anggota. Kepemimpinan adalah proses emosional secara instrinsik. Kepemimpinan terhubung dengan emosi dan rasa. Selanjutnya, bahwa pimpinan yang efektif mampu bersikap dan bertindak dalam kondisi yang berbeda atau disebut kemampuan beradaptasi. Beberapa implikasi berdasarkan asumsi usaha kepemimpinan dalam menyelesaikan masalah. Implikasi tersebut berupa:

a. Efektivitas pimpinan adalah kemampuan pimpinan untuk memberi pengaruh kepada orang lain agar mereka berkontribusi;

b. Efektivitas pimpinan adalah pengingat akan tujuan lembaga; dan

a. Efektivitas pimpinan adalah manakala pimpinan memandu dan mengarahkan kelompok untuk mencapai tujuan organisasi atau untuk menyelesaikan misi.
Chester diutip oleh Yvete Efektivitas pimpinan terkait dengan performa kerja dalam penyelesaian tugas. Riggio mengungkpakan bahwa Kepemimpinan yang efektif memerlukan beberapa kepintaran, yang membuat ia mampu merespon segala situasi yang berbeda dengan cerdas.

c. Teori Kepemimpinan

Teori kepemimpinan pada umumnya dikategorikan dalam beberapa pendekatan; trait, behavioural, contingency and influence or power approaches. Diawal tahun 1970-an pendekatan yang paling populer adalah trait, behavioural and contingency approaches.

d. Peranan Kepemimpinan

Peranan pimpinan atau kepemimpinan dalam organisasi atau perusahaan ada tiga, yaitu seperti yang dikemukakan oleh Siagian dalam tulisan Wicaksono sebagai berikut:

\section{Peranan yang bersifat interpersonal}

Peranan yang bersifat interpersonal mengandung arti bahwa seorang pimpinan dalam perusahaan atau organisasi merupakan simbol akan keberadaan organisasi, pimpinan tersebut bertanggungjawab untuk memotivasi dan memberikan arahan kepada anggota dan seorang pimpinan mempunyai peran sebagai penghubung.

2. Peranan yang bersifat informasional

Peranan yang bersifat informasional mengandung arti bahwa seorang pimpinan dalam organisasi bersifat pemberi, penerima, dan penganalisis informasi.

3. Peran pengambilan keputusan.

Peran pimpinan dalam pengambilan keputusan mempunyai arti bahwa pimpinan mempunyai peran sebagai penentu kebijakan yang akan diambil, yaitu berupa strategi-strategi bisnis yang mampu untuk mengembangkan inovasi; mengambil peluang atau kesempatan dan bernegosiasi; dan menjalankan usaha secara konsisten.

e. Komponen Dasar Pimpinan Efektif

Efektivitas menjadi output dalam sebuah siklus organisasi. Efektivitas dapat ditinjau dari tiga perspektif; individual, 
grup dan organisasi. Di mana seluruh aspek tersebut saling terkait satu sama lain. Aspek yang paling mendasar adalah effektivitas individual. Hal ini diyakini bahwa individu merupakan stimulan pertama yang kemudian beranjak kepada kelompok kerja yang lebih, kemudian bermuara pada efektivitas organisasi secara kelembagaan.

Efektivitas individual menjadi stimulan pertama dalam siklus tersebut di atas hal ini dikarenakan individual memiliki aspek-aspek yang sangat menentukan dalam proses dan hasil sebuah organisasi ketika individu tersebut menjadi salah satu sistem organisasi. Manakala seorang individu memiliki keahlian, kemampuan, pengetahuan, sikap, motivasi dan bahkan tekanan akan menentukan.

Untuk menjadi pimpinan yang memiliki tingkat efektivitas tinggi dalam memimpin tentu tidaklah mudah. Diupayakan beragam komponen dan tahapan dimiliki serta dilaksanakan oleh pimpinan tersebut. seorang pimpinan tentunya sudah harus menjalankan fungsi manajemennya; planner, organizer, leader, dan controller. Ivancevich et al., menjelaskan bahwa efektivitas dapat diciptakan dari beragam sumber. Dewi menyatakan dalam Wicaksono bahwa terdapat empat komponen model yang dikembangkan yang merupakan determinan utama yang harus dipenuhi untuk menjadi seorang pimpinan yang efektif, yaitu: 1) motif dan sifat; 2) pengetahuan, ketrampilan, dan kemampuan; 3) visi; 4) penerapan visi.

Komponen pertama adalah motif/sifat, yang berarti merupakan keinginan yang mendorong seseorang untuk bertindak. Ada beberapa motif yang umum yang wajib dimiliki oleh para pimpinan yang sukses; 1) adalah ambisi, motif ini dipandang sebagai prediktor terkuat dalam keberhasilan kepemimpinan, 2) karena bekerja dalam organisasi membutuhkan waktu yang memiliki jam kerja panjang serta kegiatan intensif maka pribadi yang enerjik dipandang perlu untuk menyelesaikan tanggungjawab tanpa kenal lelah, 3) kegigihan dan inisiatif dalam bekerja juga dipandang penting untuk selalu ditanamkan pada jiwa pimpinan yang sukses yang pantang menyerah dan giat bekerja, 4) cara penggunaan kekuasaan dinilai memiliki peran yang penting di dalam mencapai kesuksesan pimpinan.

Komponen kedua adalah pengetahuan, keterampilan dan kemampuan. Idealnya, seorang pimpinan memiliki pengetahuan dan informasi yang luas tentang organisasi, industri, dan dunia usaha agar dapat mengantarkan organisasinya menuju keberhasilan.

Komponen ketiga adalah visi yang dimiliki oleh pimpinan. Secara tegas dikemukakan bahwa visi merupakan nafas dan perasaan kepada anggota organisasi bahwa hidup dan pekerjaan mereka terjalin dan bergerak kearah tujuan yang telah disepakati secara resmi. Visi inilah yang mendominasi organisasi untuk menyongsong masa depan sehingga dalam jangka panjang tidak perlu dirubah atau diganti keberadaannya.

Komponen keempat adalah implementasi dari visi yang sudah ditetapkan. Setelah visi tercipta, maka merupakan tanggungjawab pimpinan untuk merumuskan visi stratejik serta pengkonseptualisasian dan pengevaluasian visi. Hal tersebut menunjukkan bahwa organisasi berkomitmen di dalam pemenuhan tujuan organisasi. Selanjutnya, McEwan's dikutip oleh Janet Moyles bahwa terdapat tujuh langkah menjadi pimpinan yang efektif, sebagai berikut: 1) Establish, implement and achieve academic standards, 2) Be an instructional resource for your staff, 3) Create a school culture and climate conducive to learning (for everyone), 4) Communicate the vision and mission of your school, 5) Set high expectations of your staff and yourself, 6) Develop teacher pimpinans, dan 8) Establish and maintain positive relationships with children, staff and parents. 


\section{f. Efektivitas Pimpinan PTN}

Seorang pimpinan akan mencapai tingkat efektivitas tertinggi manakala ia didukung oleh beragam faktor. Pimpinan dituntut untuk memiliki rancangan kerja yang baik, lalu kemudian ia laksanakan rancangan tersebut dalam bentuk interaksi yang baik pula, guna mencapai sebuah efektivitas. Mufllihin dikutp oleh Wicaksono kepemimpinan dilihat dari teori situasional beranggapan bahwa jenis tindakan atau kebijakan apa yang perlu dilakukan atau di ambil dalam rangka mencapai tujuan organisasi perlu dilihat bagaimana kondisi anggota atau anggota. Pada situasi anggota itu masih belum tahu banyak dan pengalamannya masih kurang, maka pimpinan dapat menerapkan pola pertama, yaitu menekankan pelaksanaan tugas yang tinggi, sedangkan hubungan dengan anggota dibatasi.

Namun lebih spesifik lagi, efektivitas kepemimpinan menurut Ivancevich et al, diutip oleh Lekka ketercapaian pimpinan dalam menyelesaikan satu atau gabungan beberapa tugas dan efektivitas kepemimpinan juga dapat dilihat dari kepuasan yang diperoleh oleh para pengikutnya. Efektivitas kepemimpinan dapat diukur dengan menggunakan dimensi Leadership Effectiveness Analysis (LEA), terdapat tiga domain yang ada yaitu developing followership, achieving results dan team playing.

Syafaruddin dikutip oleh Muhibuddin efektivitas adalah suatu keadaan yang menunjukkan keberhasilan (atau kegagalan) kegiatan kepemimpinan dalam mencapai tujuan yang telah ditetapkan terlebih dahulu. Berdasarkan beberapa pengertian di atas, bahwa efektivitas adalah kemampuan untuk menentukan pekerjaan yang benar guna mencapai tujuan yang telah ditetapkan. Dari sini dapat terlihat bahwa suatu pekerjaan dapat dikatakan efektif apabila pekerjaan tersebut dapat mewujudkan tujuan yang telah ditentukan. Efektivitas tidak hanya memberikan pengaruh atau kesan, akan tetapi berkaitan juga dengan keberhasilan tujuan, penetapan standar, efektivitas, penetapan sasaran, keberadaan program, materi, berkaitan dengan metode atau cara, sarana atau fasilitas dan juga dapat memberikan pengaruh. Chester Barnard dikutip oleh Yvete. Efektif selalu dikaitkan dengan kepemimpinan yang menentukan hal-hal apa yang diharus dilakukan, sedangkan efisien dikaitkan dengan manajemen, yang mengukur bagaimana sesuatu dapat dilakukan sebaik-baiknya. Secara sederhana, dapat dikatakan bahwa efektivitas kerja berarti penyelesaian pekerjaan tepat pada waktu yang telah ditetapkan.

Dengan melihat beberapa pengertian efektivitas di atas, dapatlah disimpulkan bahwa efektivitas lebih melihat kepada hasil akhir atau output sehingga apabila hasil akhirnya tidak sesuai dengan tujuan yang telah ditetapkan dan tidak pula memberikan efek atau pengaruh terhadap sasaran yang telah dituju, maka tidak bisa dikatakan efektif. Yang paling banyak digunakan untuk mengukur efektivitas pimpinan adalah seberapa jauh unit organisasi pimpinan tersebut berhasil menunaikan tugas pencapaian sasarannya. Contohnya adalah keuntungan, peningkatan kualitas, dan pangsa pasar. Indikator umum lainnya adalah sikap para pengikut terhadap pimpinan yang tercermin pada tingkat penghormatan, penghargaan, kesukaan, komitmen terhadap tugas dan pemenuhan kebutuhan anggota. Serta perilaku para pengikut seperti tingkat kehadiran, kedisiplinan, keluhan sabotase, dan motivasi. Efektivitas kepemimpinan juga kadang-kadang diukur berdasarkan kontribusi pimpinan pada kualitas proses kelompok yang dirasakan oleh para pengikut. Seperti peningkatan kerja sama, solidaritas, pengambilan keputusan, pemecahan konflik, peningkatan kesiapan kelompok dalam menangani perubahan, perbaikan kualitas hidup para pengikut dan pembentukan rasa percaya diri.

Mardiana dikutip oleh Wicaksono beberapa faktor penting situasional yang mempengaruhi keefektivitasan 
kepemimpinan adalah kualitas hubungan pimpinan-anggota, tingkat struktur dalam tugas yang akan dikerjakan, dan kekuatan posisi pimpinan.

Selanjutnya Brian Dive mengatakan bahwa kepemimpinan tergantung kepada kemampuan seseorang dalam memimpin orang lain (kelompok). Efektivitas kepemimpinan bergantung kepada beberapa hal sebagai berikut: 1) an accountable role;2) a healthy, effective organizational infrastructure of roles;3) a well-balanced; 4) competent individual.

Namun faktanya, sebagian besar organisasi cenderung hanya fokus kepada bagian ke tiga saja. Bahkan pada bagian yang ke dua cenderung diabaikan. Itulah mengapa begitu banyak pimpinan tidak mampu menjadi pimpinan yang akuntabel dan efektif. Tiga dimensi kemungkinan yang dapat mendefinisikan faktor situasional utama (kunci) yang menentukan keefektifan kepemimpinan. Ketiga dimensi tersebut adalah:

1. Hubungan pimpinan-anggota

Hubungan pimpinan anggota menunjukkan sejauh manaseorang pimpinan mendapatkan dukungan dan loyalitas daripada anggota dan hubungan dengan para anggota itu bersahabat dan saling membantu.

\section{Struktur tugas}

Pada struktur tugas terdapat prosedur pengoperasian yang standar untuk menyelesaikan tugas dan indikator obyektif tentang seberapa baik tugas itu dikerjakan. Struktur tugas yang tinggi akan memberikan kontribusi pada situasi yang menguntungkan pimpinan karena pimpinan akan lebih mudah memonitor dan mempengaruhi perilaku anggotanya pada tugas yang terstruktur tinggi. Sedangkan tugas yang tidak terstruktur akan memberikan kontribusi yang tidak menguntungkan pimpinan, sehingga kemampuan pimpinan untuk mengontrol anggotanya rendah.

3. Kekuatan posisi pimpinan

Pada kekuatan posisi pimpinan terdapat tingkat wewenang pimpinan untuk mengevaluasi pelaksanaan kerja anggota, memberikan penghargaan, promosi, hukuman, dan demosi. Semakin besar kekuasaan formal seorang pimpinan untuk memberikan hukuman dan penghargaan, semakin kuat kontrol pimpinan, dan hal ini membuat situasi semakin memungkinkan.

Gibson dikutip oleh Wicaksono hubungan antara sifat pimpinan, perilaku pimpinan, variabel situasional, dan efektivitas organisasi dalam sebuah model. Efektivitas diukur dengan beberapa indikator: 1) kepuasan kerja, 2) produktivitas, 3) kualitas, 4) efisiensi, 5) fleksibilitas, 6) daya saing, dan 7) pengembangan.

Model tersebut menjelaskan bahwa perilaku pimpinan dipengaruhi oleh sifat pimpinan dan berhubungan timbal balik dengan variabel situasional. Model tersebut juga menjelaskan pengaruh perilaku pimpinan dan variabel situasional terhadap efektivitas organisasi.

Sangat sulit untuk mengevaluasi pimpinan yang efektif karena terdapat banyak alternatif ukuran efektivitas, dan tidak jelasnya ukuran mana yang paling relevan. Syarafuddin dikutip Muhibuddin ukuran efektivitas kepemimpinan sebagai berikut: a) proses kerjanya berdasarkan standar penampilan dalam membuat perencanaan, mengorganisir, memotivasi dan mengawasi, b) karakteristik kepribadian, kemampuan, sikap, keteladanan dan keterbukaan, dan c) tingkat penyelesaian tugas dalam pencapaian tujuan yang muaranya pada mutu produk dan mutu pelayanan.

Sehingga berdasarkan beragam referensi di atas maka dapat disintesiskan bahwa efektivitas pimpinan PTN merupakan ketercapaian pimpinan dalam menyelesaikan satu atau gabungan beberapa tugas dalam pengelolaan program studi dengan dimensi; hubungan pimpinananggota, struktur tugas dan kewenangan atasan. Efektivitas pimpinan tersebut dapat terlihat dari beberapa indikator; penerimaan, rasa percaya, dukungan kerja, standar kerja dan kewenangan atasan. 


\section{PENUTUP}

Pemimpin yang efektif merupakan orang-orang dengan motivasi tinggi dalam memimpin dan mengendalikan organisasi, para pemimpin yang efektif dengan sukarela akan berusaha mencapai sasaran dan target yang tinggi dengan menetapkan standar-standar prestasi yang tinggi bagi mereka sendiri. Pemimpin efektif mempunyai sifat energik, menykai segala sesuatu yang sifatnya menantang dan menykai permasalahan-permasalahan sulit dan tidak terpecahkan yang muncul di lingkungan organisasi. Seorang pemimpin efektif akan berusaha mengubah keinginan seseorang untuk melakukan sesuatu hal dengan menunjukkan arah yang harus ditempuh dan membina anggota kelompok kearah penyelesaian hasil pekerjaan kelompok.

Didalam suatu organisasi terdapat dua pengaruh yang timbul dari hubungan antara pimpinan dan anggota organisasi, maksudnya terdapat interaksi dan reaksi timbal balik dari orang-orang yang ada dalam suatu organisasi. Seorang pemimpin mempunyai misi atau tujuan yang ingin dicapainya, pemimpin akan berusaha menterjemahkan misi tersebut dengan mendorong para pengikutnya hingga mencapai tingkat prestasi yang cukup memuaskan (misi organisasi).

Kepemimpinan efektif berkaitan dengan masalah pimpinan dalam meningkatkan kesempatan untuk mengadakan pertemuan secara efektif dengan para anggota dalam situasi kondusif. Perilaku pimpinan harus dapat mendorong kinerja para anggota dengan menunjukkan rasa bersahabat, dekat dan penuh pertimbangan terhadap anggota, baik sebagai individu maupun sebagai kelompok. Perilaku pemimpin yang positif dapat mendorong kelompok dalam mengarahkan dan memotivasi individu untuk bekerjasama dalam kelompok dalam rangka mencapai tujuan Institusi.

Setiap orang mempunyai sekedar pengaruh atas yang lain, dengan praktek. Pengaruh ini jadi tumbuh, sebagian orang lebih banyak dipengaruhi oleh orang lain, dan sebagaian kondisi lebih banyak dapat digunakan untuk mempengaruhi. Kita dapat memandang kepemimpinan sebagai kemampuan seseorang atau pemimpin untuk mempengaruhi prilaku orang lain menurut keinginan-keinginan dalam suatu keadaan tertentu.

\section{DAFTAR PUSTAKA}

[1]. Ady Baskoro Wicaksono dan Sugeng Wahyudi, 2011, Pengaruh Efektivitas Kepemimpinan terhadap Kepuasan Kerja Pegawai, Jakarta.

[2]. Brian Dive, 2008, The Accountable Leader (London and Philadelphia: Kogan Page.

[5]. Chrysanthi Lekka, et al., 2012, A Review of Literature on Effective Leadership Behaviours for Safety, London: Crown.

[6]. Eri Muhuhibuddin, 2010, Efektivitas Kepemimpinan, Jakarta.

[7]. Luthans, Fred, 2011, Organizational Behaviour: an Evidence-Based Approach, $12^{\text {nd }}$ edition, New York: McGraw-Hill.

[8]. Ivancevich, et al., 2012, Organizations: Behaviour, Structure and Process, New York: McGrawHill.

[9]. Janet Moyles, 2006, Effective Leadership and Management in The Early Years, New York: Open University Press.

[10]. Luthans, Fred, 2011, Organizational Behaviour: an Evidence-Based Approach, $12^{\text {nd }}$ edition, New York: McGraw-Hill.

[11]. Yvete Ramchunder, 2012, The Role of Emotional and Self-Efficacy as Attributes of Leadership Effectiveness, South Africa. 